\title{
Social capital in Spain: Are there gender inequalities?
}

\author{
Celia Muñoz-Goy, University of A Coruña
}

\begin{abstract}
Social capital is an asset for individuals because it grants access to important resources embedded in their social networks. But social capital is not evenly distributed among different groups. Gender groups are analysed in this paper in order to examine if there are differences in diverse indicators of social capital and whether these possible differences remain when control variables are considered. The data used in this paper come from a representative sample of 3,400 people in Spain. The main results show gender differences in the access, mobilisation and type of social networks, as well as in the extent and type of social participation. However, these differences are mostly reduced for the groups in more advantageous social positions, which have the possibility to contact with greater and more varied groups, or which have been educated in less traditional gender roles. In general, gender inequalities in social capital remain for the other groups.
\end{abstract}

\section{JEL classification}

Z13; J16

\section{Keywords}

Social capital; social networks; civic participation; gender inequalities 


\section{Introduction}

Over the last few years, there has been a growing interest in social capital in the fields of sociology and economics. Some of the more salient authors have considered social capital either as potential or actual resources linked to the presence in networks of relationships (Bourdieu, 1985) or as aspects of the social structure that facilitate certain actions of the individuals within that structure (Coleman, 1988) or as features of the social organisation, that is to say networks, norms and social trust, which facilitate connections among individuals as well as coordination and cooperation for mutual benefits (Putnam, 1995).

Even if there still is an open debate about the definition and measurement of this wide concept (Dasgupta and Serageldin, 2001), social capital can be understood as a resource available to individuals derived from their location on a structure of social relations (Adler and Kwon, 2002: 18). The importance of this resource is that it improves the chances of obtaining a very wide variety of benefits, ranging from instrumental rewards, such as faster promotions or better jobs, to expressive rewards such as better mental health and even an increased subjective feeling of well-being or life satisfaction (Adler and Kwon, 2002; Lin, 2000; Kroll, 2011).

But access to social capital and the benefits derived therein is not evenly distributed among all individuals or social groups. As Lin (2000: 786-787) explains, depending on the historical processes and institutional construction of societies, some groups defined by race, gender, religion, caste, and other ascribed or constructed characteristics, are provided with unequal opportunities compared with the members of other social groups. And this phenomenon is more prevalent when combined with another principle, named homophily, which points out that individuals tend to interact more frequently with members in their own group, or in groups with similar socioeconomic characteristics. As a consequence of this tendency, members of disadvantaged social groups will share a lower variety of information and influence than members of resource-rich networks.

It is precisely women who make up a social group with a disadvantaged socioeconomic status compared to men, and who tend to establish links with other peers or similar groups. As follows from the work of Gwen Moore (1990), there are differences in the composition of male and female social networks in the United States in the 1980's. Although many of these differences decrease when controlling variables related to employment status, family and age, some variations still remain, especially regarding the type of social networks, because women tend to connect mainly with the family, while men extend their networks of relationships beyond parental ties.

Maxine Molyneux (2008: 68) has also found gender differences, shown by the fact that women's social capital is located more so at home rather than in the public environment of the workplace, and involves exchanges of time and money as opposed to capabilities. It includes a significant proportion of voluntary work and undertaking the role of a carer and usually involves affective or ethical issues, a degree of altruism and often mobilises feelings associated with motherhood. So, this social capital creates strong ties (bonding social capital) more so than weak links (bridging social capital). These differences imply that women's networks are located in areas different to those of men's capital. While men's networks are traditionally associated with the public world of the workplace and politics, women's networks focus more on solving domestic problems and less on economic and employment issues. This situation reflects the fact that, despite the changes that have occurred in recent decades, women are still in an unequal power situation, and thus continue to carry out the majority of family duties, having fewer resources and less power than men.

Other studies note the gender inequality in relation to the mobilisation of social capital, or the potential use of the resources embedded in the network. As pointed 
out by Lin (2000: 791), in the specific area of the labour market, men have greater advantages than women, either because women do not use or do not mobilise the adequate social capital, or because they mobilise the adequate social links but these links are reluctant to invest in their favour, or even because there are different responses from the labour market itself depending on whether candidates sought for a job or promotion are male or female. Timberlake (2005: 43) also concludes in his analysis that women are less able to mobilise social capital to get better jobs and seek promotion in organisations where they work.

Furthermore, Pippa Norris and Ronald Inglehart (2006) analyse the participation in community life, as an indicator of social capital, since this participation facilitates the establishment of networks and the achievement of individual benefits, such as opportunities in the workplace and the availability of support networks that encourage collaboration channels to solve local problems. These authors distinguish two types of inequality on civic engagement: horizontal segmentation and vertical segmentation.

Vertical segmentation refers to the differences in the intensity of organisational participation of men and women, while horizontal segmentation takes into account the differences in the type of organisations to which men and women belong. It is in this latter type of horizontal segmentation that Norris and Inglehart (2006) have found differences according to gender, in the U.S. and in most countries they have analysed. On the one hand, male participation is clearly superior in recreational associations, unions, political parties and professional associations, while, on the other hand, women tend to participate more in voluntary associations related with education, religious organisations and groups devoted to help the disabled or the elderly, as well as women's groups.

Regarding vertical segmentation, men participate in organisations to a higher degree than women, even when controlling variables related to structural factors (age, education) and cultural values (ideology, religion), but vanish when controlling agency factors, or the impact of relationships with others who can encourage participation (time spent with family, friends or co-workers).

As shown by the previous studies, there are social capital inequalities according to gender, although some differences may be reduced or even disappear if certain control variables are taken into account. This research topic has a theoretical interest since it elucidates the relationships between social capital and structural and socioeconomic factors. It also has a social interest because knowledge in this area can contribute to the decision-making in policies to reduce gender inequalities.

In this paper, I analyse individual social capital inequalities according to gender in Spain, to test if significant differences occur and whether these differences are maintained or not in the presence of several control variables. The control variables -education level, age, occupational status, employment status, marital status and having or not dependants- reflect several structural aspects that could affect civic engagement and the establishment of social networks, promoting or restraining the availability of a range of resources such as time, money, knowledge and skills. To carry out this analysis I consider whether there are gender differences in several social capital indicators: network variety, possible use or mobilisation of resources, type of network and social participation. In a more detailed manner, I test the following hypotheses:

H1. The more advantaged gender group (men) will have more social capital than the less advantaged gender group (women):

\section{H1.1. Women are expected to have less network variety than men.}

H1.2. Women are expected to have fewer possibilities of use or mobilisation of resources from their networks than men. 
H2. Gender groups are expected to differ on the type of networks: women are expected to have more internal or family link while men are expected to connect with more external groups.

H3. Gender groups are expected to have different patterns of social participation:

H3.1. Women are expected to have lower levels of social participation than men (vertical segmentation).

H3.2. Women and men are expected to participate in distinctive types of social organisations (horizontal segmentation).

After testing these hypotheses for the whole sample under analysis, I create separate subgroups, using the aforementioned control variables, to confirm whether or not the expected relationships between gender and social capital indicators remain when considering the effect of structural factors.

\section{Data and measures}

In this paper I use the data base "Social Capital and Inequality in Spain", from the research group OSIM (Social Organisations, Institutions and Markets) of the University of A Coruña, Spain. Data collection took place between November and December of 2011 , with telephone interviews (CATI) to 3,400 people aged 18 or over, residing in Spain. The total error estimated for this sample size is $\pm 1.7 \%$ for global data, assuming a confidence level of $95.5 \%$ and $P=Q$. The sample was stratified according to autonomous communities (the Spanish regions) using a mixed procedure: half of the sample size was assigned proportionally according to population size of the autonomous community, and the other half of the sample size was divided disproportionally to ensure a minimum of 100 interviews in each one of the 17 autonomous communities. In each autonomous community, there was a proportional distribution of the sample according to the size of municipalities. Weighting based on the national distribution of gender, age groups and size of autonomous communities, was introduced to adjust sampling data.

\section{Measures of social capital}

Not only is there a plethora of definitions of social capital, but there are also many different ways of measuring the concept. In this paper I analyse various indicators of individual social capital, accounting for diverse aspects that may facilitate a person attaining the resources embedded in its net of social relations. As stated in the hypotheses, our interest lies in the variety and potential use of networks, the type of networks and the social participation.

The variety of network, or accessibility, considered as the diversity of contacts that a person can access, is an indicator of social capital, since the larger the network size the greater the likelihood of achieving various resources.

Accessibility or the variety of network was measured using the data of a question with 14 items. Respondents were asked to report if among their family, friends or acquaintances, there was someone with certain characteristics included in a list of the survey as shown in Table 1 . Should the respondent answer affirmatively that he or she has a relative with one of the mentioned characteristics, the response is collected not recording whether the person also has friends and/or acquaintances with those characteristics.

To summarise the information of this question we added up the number of different characteristics each respondent knows, regardless of whether they are relatives, friends or acquaintances, and expressed such amount in percentages. 
Table 1. List of items included in the measures of variety of network (Colum A) and the network mobilisation (Colum B)

\begin{tabular}{|c|c|}
\hline $\begin{array}{l}\text { VARIETY OF NETWORK: } \\
\text { Is there anyone, among your relatives, friends or } \\
\text { acquaintances, with the following characteristics? }\end{array}$ & $\begin{array}{c}\text { NETWORK MOBILISATION: } \\
\text { Is there anyone, among your relatives, friends or } \\
\text { acquaintances, who could help you out in the } \\
\text { following situations? }\end{array}$ \\
\hline An university professor & Finding a job for a family member \\
\hline $\begin{array}{c}\text { A person working in the administration of the } \\
\text { education system }\end{array}$ & Giving advice in a labour dispute \\
\hline A person working in the legal system & Helping to move \\
\hline A person working in the tax office & Giving advice or help in educational matters \\
\hline $\begin{array}{c}\text { A person working in local government (but not as a } \\
\text { politician) }\end{array}$ & Helping with the shopping when is sick \\
\hline A person working in the banking system & $\begin{array}{c}\text { Giving medical advice when the respondent is } \\
\text { dissatisfied with a doctor }\end{array}$ \\
\hline A doctor & Lending a large amount of money (e.g. $€ 5,000$ ) \\
\hline $\begin{array}{c}\text { A person working in the health service (but not a } \\
\text { doctor) }\end{array}$ & $\begin{array}{l}\text { Lending a place to live while the respondent } \\
\text { cannot use his or her home }\end{array}$ \\
\hline A policeman/policewoman & Giving advice on tax issues \\
\hline A person holding a political office & Giving advice on financial issues \\
\hline $\begin{array}{l}\text { A journalist or someone having influence on the } \\
\text { media }\end{array}$ & Giving advice on legal matters \\
\hline $\begin{array}{l}\text { A person having the opportunity to hire people } \\
\text { A person earning over } € 3,000 \text { a month }\end{array}$ & $\begin{array}{l}\text { Providing good references when looking for a job } \\
\text { Helping to take care of children }\end{array}$ \\
\hline $\begin{array}{l}\text { A person having more than one million euros, or } \\
\text { that the respondent thinks is a very rich person }\end{array}$ & Helping to take care of the disabled or the elderly \\
\hline
\end{tabular}

Source: OSIM Survey on social capital in Spain, 2011

Another indicator of social capital is network mobilisation, understood as the possibility of effectively using the social contacts to obtain resources embedded in the net. Mobilisation was measured using the data of a question with 14 items. Respondents were asked to report if among their family, friends or acquaintances, there was someone that might help him or her in different situations as shown in Table 1. The situations of the list are hypothetical ones, meaning that there is no need for the respondent to be actually in the situation, but must answer as if the situation could happen, so, for example, people without children or elderly to their charge are asked to answer as if he or she would be in such case. To summarise the information of this question, we proceeded in the same way as explained for the variety of network or accessibility.

Analyzing social capital, as aforementioned, different contributions (Moore, 1990; Molyneux, 2008) found differences according to gender in the type of social networks, in the sense that men's networks tend to be extra parental or placed in a public environment (bridging social capital) while women's networks tend to be more focused on parental or domestic areas (bonding social capital).

To substantiate these claims, I analyse the information from the question about the variety of social network, creating three variables to express in percentages the type of network composition, taking into account whether the contacts mentioned by the respondents are mainly focused on family, friends or acquaintances.

Finally, participation in community life is often used as an indicator of social capital, since such participation facilitates the establishment of networks. Specifically, Robert Putnam (2000) uses the downward trend of civic participation in the United States as an indicator of the decline of social capital in that country. To measure social participation, I use the information from the question based on the voluntary organisations to which respondents belong, from a total of eight different categories: religious organisations; sports organisations; art, music or educational organisations; trade unions; political parties; associations related to ecology and environmental associations; professional associations; NGOs (social welfare, health, human rights, humanitarian). This information was treated from a double perspective, to analyse the vertical and horizontal segmentation. As a measure of vertical segmentation, we added up the total number of organisations to which 
each respondent belongs, and so as to explore horizontal segmentation I compare the specific type of organisations to which men and women adhere.

To test the hypotheses outlined in the previous section, I compare the summary measures of the different indicators of social capital by gender, using an analysis of variance (ANOVA) or a Chi-Square test, depending on whether the summary is a mean or a percentage. After this first comparison, I shall explore whether or not gender differences are still significant among groups formed by introducing the control variables - education level, age, occupational status, employment status, marital status and having or not dependants. Some of these variables have been recoded to avoid comparisons among an excessive number of categories and low sampling sizes. The distributions of sample sizes for independent variables are shown in Table 2. As for education, the group named as low level corresponds to primary education or less, the group named as moderate level corresponds to secondary education and vocational training, and the group named as high level corresponds to university-level education. A special comment deserves the grouping of age; we have decided to use three groups in line with other research strategies and the youngest group (under 35 ) corresponds to the grouping of the original groups of 18-24 and 25-34. Regarding the variable about having dependants or not, there is no distinction in the original wording of the questionnaire among those having children and those taking care of elderly or other dependent adults.

Table 2. Description of the sample by independent variables

\begin{tabular}{cccc}
\hline & & Women & Men \\
\hline All & High & 1736 & 556 \\
Education & Moderate & 548 & 814 \\
& Low & 772 & 282 \\
& Under 35 & 399 & 502 \\
Age groups & $35-64$ & 479 & 864 \\
& 65 or more & 855 & 297 \\
& Manager/professional & 401 & 197 \\
Occupational status & Middle range & 123 & 202 \\
& supervisors & 196 & 387 \\
& Skilled working & 198 & 123 \\
Work status & Unskilled working & 204 & 894 \\
& In paid work & 698 & 769 \\
Marital status & Not in paid work & 1038 & 1026 \\
& Married or cohabiting & 1021 & 508 \\
Dependants & Single & 384 & 543 \\
& Yes & 581 & 1120 \\
\hline
\end{tabular}

Source: Author, based on data from OSIM Survey on social capital in Spain, 2011.

\section{Data analysis}

\section{Accessibility and gender}

Results for the network variety show gender differences as expected and in line with previous analyses (Table 3). There are significant differences in the mean of accessibility by gender, supporting the hypothesis that states that men have more diversified social networks than women. However, the network variety differences by gender are modified in some cases when controlling other structural factors.

The level of education has an evident impact on network variety, since the higher the level of education, the greater the accessibility to a more diversified social network for both men and women, in accordance with previous analysis that established the crucial role of education in social capital generation (Huanga, et al. 2009). But when controlling this variable, we found that among people with a higher level of education, gender differences are not statistically significant, while at the other levels of education, gender inequity in social capital persists. 
In terms of age, there is no such direct relationship with network accessibility as in the case of the level of education, but we can see that such accessibility is lower among the elderly than among the younger and middle age group. We also observe that among younger people there are no gender differences in the size of the social network.

Table 3. Mean of accessibility according to gender and control variables

\begin{tabular}{|c|c|c|c|c|c|}
\hline & & Women & Men & Difference & Sig. 1 \\
\hline \multirow[t]{2}{*}{ All } & & 32.93 & 36.79 & -3.86 & $\star \star \star *$ \\
\hline & High & 45.43 & 47.21 & -1.79 & n.s. \\
\hline \multirow[t]{3}{*}{ Education } & Moderate & 31.21 & 34.86 & -3.64 & $* *$ \\
\hline & Low & 19.57 & 22.93 & -3.36 & * \\
\hline & Under 35 & 36.36 & 37.50 & -1.14 & n.s. \\
\hline \multirow[t]{3}{*}{ Age groups } & $35-64$ & 36.29 & 39.29 & -3.00 & * \\
\hline & 65 or more & 21.71 & 28.50 & -6.79 & $* * *$ \\
\hline & $\begin{array}{c}\text { Manager/profe } \\
\text { ssional }\end{array}$ & 49.21 & 49.29 & -0.07 & n.s. \\
\hline \multirow{3}{*}{$\begin{array}{l}\text { Occupational } \\
\text { status }\end{array}$} & $\begin{array}{l}\text { Middle range } \\
\text { supervisors }\end{array}$ & 44.43 & 46.07 & -1.64 & n.s. \\
\hline & $\begin{array}{l}\text { Skilled } \\
\text { working }\end{array}$ & 33.07 & 30.36 & 2.71 & n.s. \\
\hline & $\begin{array}{l}\text { Unskilled } \\
\text { working }\end{array}$ & 20.14 & 25.86 & -5.71 & * \\
\hline \multirow[b]{2}{*}{ Work status } & In paid work & 41.21 & 41.07 & 0.14 & n.s. \\
\hline & $\begin{array}{l}\text { Not in paid } \\
\text { work }\end{array}$ & 27.43 & 31.86 & -4.43 & $* * *$ \\
\hline \multirow{2}{*}{ Marital status } & $\begin{array}{l}\text { Married or } \\
\text { cohabiting }\end{array}$ & 33.71 & 38.64 & -4.93 & $* * *$ \\
\hline & Single & 37.14 & 34.00 & 3.14 & n.s. \\
\hline \multirow{2}{*}{ Dependants } & Yes & 38.21 & 41.64 & -3.43 & * \\
\hline & No & 30.29 & 34.43 & -4.14 & $* * *$ \\
\hline
\end{tabular}

Source: Author, based on data from OSIM Survey on social capital in Spain, 2011.

1 Level of statistical significance of ANOVA: n.s. = not significant, ${ }^{*}: p \leq 0.05 ;{ }^{* *}: p \leq 0.01 ;{ }^{* *}: p \leq 0.001$

Higher occupational status seems related to more network variety, but it is also important to note that in most of the groups defined by occupation no gender differences were found. The only exception appears in the group of unskilled workers, where men have significantly higher network accessibility than women.

With reference to the labour market, people having paid work show higher accessibility means than unemployed people. It is important to highlight the fact that the average social network variability is almost equal between men and women who are in paid employment, suggesting that either being employed helps people to expand their network and makes gender differences vanish, or it is precisely those women with high social capital who are part of the labour market and for that reason gender inequality in network accessibility disappears.

In terms of marital status, married men have higher accessibility than married women, while among those who are single there is a slight difference in favour of women although such difference is not statistically significant. In other words, accessibility differences by gender vanish among single people.

Moreover, people who have children or dependants have higher network accessibility than people with no dependants, but gender differences continue to be significant in both groups, showing more variety of social networks for men than for women.

In summary, the network accessibility differences according to gender are significant in all groups except among people with a higher level of education and those who are young, single and with a medium or high level of occupational status. The disappearance of gender differences in these cases could be due to the fact that it is precisely the younger women who have higher levels of education and are therefore more likely to join the labour market -even at intermediate or higher level occupations- that gives them access to a public sphere where they can 
establish a wider range of contacts. In this way, they overcome the phenomenon of homophily described by Lin (2000), and so they participate in the conditions in which men have traditionally established their social networks.

\section{Mobilisation of social network and gender}

As shown in Table 4, men have a higher average of resource mobilisation than women, but such differences are no longer significant for some groups formed when controlling structural factors.

Table 4. Mean of network mobilization according to gender and control variables

\begin{tabular}{|c|c|c|c|c|c|}
\hline & & Women & Men & Difference & Sig.1 \\
\hline \multirow[t]{2}{*}{ All } & & 58.71 & 63.21 & -4.50 & 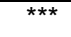 \\
\hline & High & 71.86 & 73.50 & -1.64 & n.s. \\
\hline \multirow[t]{3}{*}{ Education } & Moderate & 59.64 & 63.21 & -3.57 & * \\
\hline & Low & 39.71 & 44.21 & -4.50 & * \\
\hline & Under 35 & 71.50 & 70.64 & 0.86 & n.s. \\
\hline \multirow[t]{3}{*}{ Age groups } & 35-64 & 60.57 & 65.21 & -4.64 & $* *$ \\
\hline & 65 or more & 39.57 & 44.79 & -5.21 & * \\
\hline & $\begin{array}{l}\text { Manager/profe } \\
\text { ssional }\end{array}$ & 74.43 & 74.00 & 0.43 & n.s. \\
\hline \multirow{4}{*}{$\begin{array}{l}\text { Occupational } \\
\text { status }\end{array}$} & $\begin{array}{l}\text { Middle range } \\
\text { supervisors }\end{array}$ & 68.21 & 68.93 & -0.71 & n.s. \\
\hline & $\begin{array}{c}\text { Skilled } \\
\text { working }\end{array}$ & 61.50 & 56.07 & 5.43 & * \\
\hline & $\begin{array}{l}\text { Unskilled } \\
\text { working }\end{array}$ & 47.36 & 54.07 & -6.71 & * \\
\hline & In paid work & 67.86 & 69.21 & -1.36 & n.s. \\
\hline Work status & $\begin{array}{l}\text { Not in paid } \\
\text { work }\end{array}$ & 52.57 & 56.21 & -3.64 & ** \\
\hline \multirow[t]{2}{*}{ Marital status } & $\begin{array}{l}\text { Married or } \\
\text { cohabiting }\end{array}$ & 58.93 & 62.93 & -4.00 & $* *$ \\
\hline & Single & 69.00 & 66.36 & 2.64 & n.s. \\
\hline \multirow{2}{*}{ Dependants } & Yes & 64.64 & 65.29 & -0.64 & n.s. \\
\hline & No & 55.79 & 62.21 & -6.43 & $* \star \star *$ \\
\hline
\end{tabular}

Source: Author, based on data from OSIM Survey on social capital in Spain, 2011.

1 Level of statistical significance of ANOVA: n.s. = not significant, ${ }^{*}: p \leq 0.05 ;{ }^{* *}$ : $p \leq 0.01 ;{ }^{* *}$ : $p \leq 0.001$

The higher the level of education, the greater is the mobilisation of resources. And it is precisely in the group of people with a high level of education where gender differences vanish. The same happens with age; the mobilisation of resources in the network is higher when we consider younger groups, and among the youngest people there are no differences by gender in this indicator of individual social capital.

The mobilisation of resources in the network is higher as we move to upper positions in the occupational status scale. And for the groups of managers/professionals and middle range supervisors the differences of mobilisation between men and women are not statistically significant.

People in paid work have more possibilities to use their network resources in comparison to unemployed people. Among the first group there are no clear differences according to gender, showing that access to the labour market opens up the possibility to establish contacts that will expand the available span of resources.

The mobilisation of resources in the network is lower for married people than for single people and among the latter there are no significant gender differences on mobilisation. The group of people having dependants show a greater resource mobilisation than the group without dependants, which may reflect that the need to take care of others leads to generating a stronger network where to extract resources from. Among those with dependants, no differences by gender were found in the mobilisation of the network. 
In summary, in general terms, the findings on the relationship of the mobilisation of resources in the network and gender are similar and consistent with those for network accessibility: gender differences are not significant among those with higher levels of education, those who are young, single and with high or medium occupational status, yet it remains significant in the other cases.

\section{Type of network and gender}

The analysis of type of network (Table 5) demonstrates that links with family members are more common for women than for men, but the difference is not significant. Furthermore, considering the groups formed in accordance with the control variables, we also observe that, in most of the cases, women have higher rates of family networks than men, but there are practically no cases with statistically significant differences. The only exception is the group of single people.

Distinct results are found for the network of friends as notable differences are appreciated. Women have a lower percentage of network composition based on friends than men. And this difference in favour of men holds and remains significant in the presence of most of the control variables.

However, gender inequality vanishes in some cases that coincide with those that were mentioned when analyzing network accessibility, i.e. those groups with a higher level of education, youngest in age, in a high or medium occupational status, who have paid work and who are single people. In addition, there are also no differences in the network of friends among people who have to take care of children or dependants. 
Table 5. Mean of type of network according to gender and control variables

\begin{tabular}{|c|c|c|c|c|c|c|c|c|c|c|c|c|c|}
\hline & & \multicolumn{4}{|c|}{ Family network } & \multicolumn{4}{|c|}{ Friends network } & \multicolumn{4}{|c|}{ Acquaintance network } \\
\hline & & $\begin{array}{l}\frac{\bar{q}}{\xi} \\
\sum^{\circ}\end{array}$ & $\sum^{\frac{c}{0}}$ & 岌 & क्⿹ & 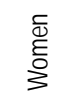 & $\sum^{\frac{c}{N}}$ & 荡 & 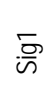 & 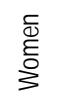 & $\sum^{\frac{c}{0}}$ & 荡 & in \\
\hline $\bar{\varangle}$ & & 15.22 & 14.73 & 0.49 & n.s. & 11.40 & 14.15 & -2.75 & $\star \star \star ~$ & 6.33 & 7.93 & -1.60 & $\star \star \star ~$ \\
\hline \multirow{3}{*}{ 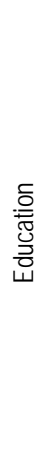 } & 市 & 19.15 & 19.28 & -0.14 & n.s. & 18.68 & 18.74 & -0.05 & n.s. & 7.63 & 9.23 & -1.60 & n.s. \\
\hline & 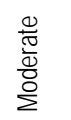 & 14.75 & 13.60 & 1.16 & n.s. & 10.29 & 13.91 & -3.62 & $* * *$ & 6.20 & 7.35 & -1.15 & n.s. \\
\hline & z̧ & 11.01 & 9.28 & 1.73 & n.s. & 3.80 & 6.38 & -2.59 & ** & 4.77 & 7.30 & -2.53 & ** \\
\hline \multirow{3}{*}{$\begin{array}{l}\frac{0}{3} \\
0 \\
0 \\
0 \\
8\end{array}$} & 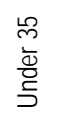 & 15.28 & 14.67 & 0.61 & n.s. & 14.48 & 15.01 & -0.53 & n.s. & 6.59 & 7.82 & -1.23 & n.s. \\
\hline & $\begin{array}{l}\text { ठ } \\
\text { 山్ }\end{array}$ & 16.03 & 15.35 & 0.68 & n.s. & 13.30 & 15.66 & -2.36 & ** & 6.99 & 8.26 & -1.28 & n.s. \\
\hline & $\begin{array}{l}0 \\
\overline{0} \\
0 \\
\emptyset \\
0\end{array}$ & 13.41 & 13.03 & 0.38 & n.s. & 3.68 & 8.28 & -4.61 & $* \star \star$ & 4.63 & 7.17 & -2.54 & ** \\
\hline \multirow{3}{*}{ 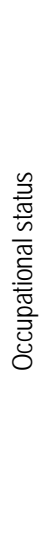 } & 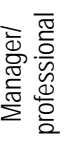 & 18.03 & 19.80 & -1.77 & n.s. & 24.00 & 21.11 & 2.88 & n.s. & 7.20 & 8.34 & -1.13 & n.s. \\
\hline & 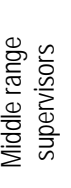 & 20.32 & 19.08 & 1.24 & n.s. & 17.77 & 16.99 & 0.78 & n.s. & 6.32 & 10.02 & -3.70 & ** \\
\hline & $\begin{array}{l}\frac{8}{5} \\
\frac{5}{0} \\
\frac{0}{8} \\
\frac{9}{5} \\
\frac{7}{6}\end{array}$ & 14.60 & 12.60 & 2.00 & n.s. & 10.76 & 10.97 & -0.20 & n.s. & 7.70 & 6.75 & 0.95 & n.s. \\
\hline
\end{tabular}




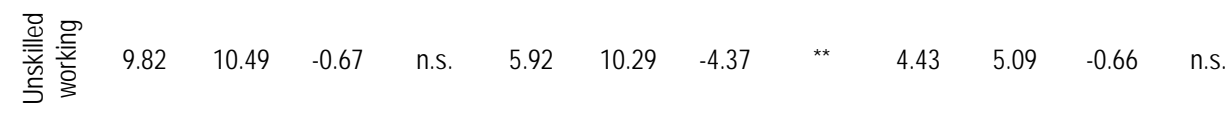

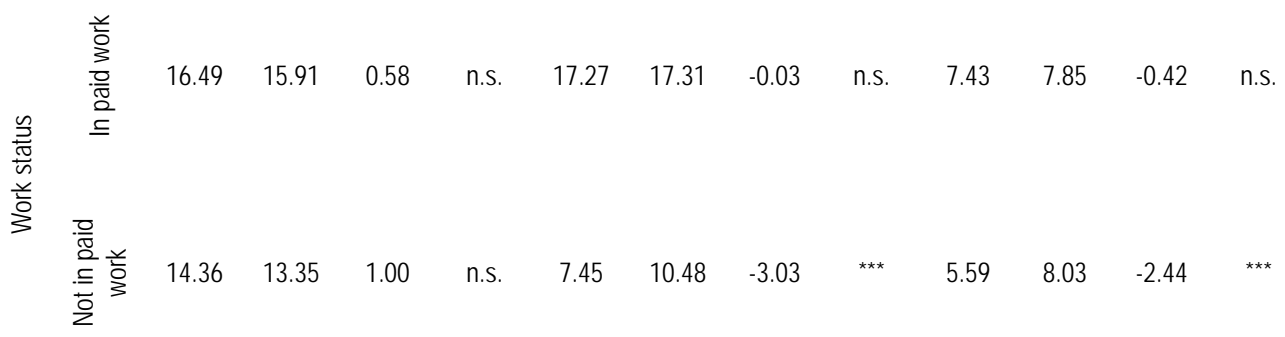

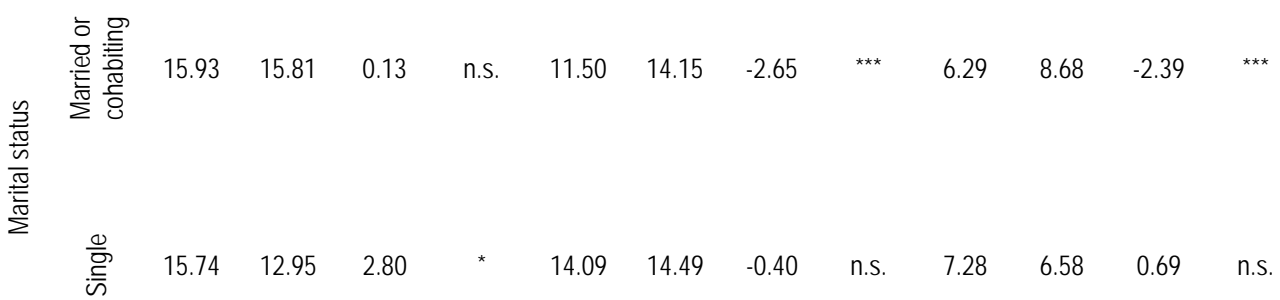

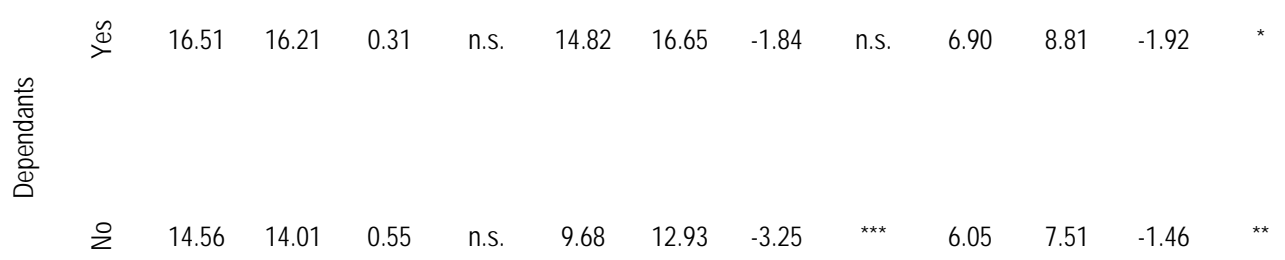

Source: Author, based on data from OSIM Survey on social capital in Spain, 2011.

1 Level of statistical significance of ANOVA: $n . s .=$ not significant, ${ }^{*}: p \leq 0.05 ;{ }^{* *}: p \leq 0.01 ;{ }^{* * *}: p \leq 0.001$

Regarding the last type of networks, women have significantly fewer links with acquaintances than men. However, this difference is somehow modified by taking into account the control variables in a similar way as with the network of friends. In other words, in most of the cases it holds true that men have a network of acquaintances significantly greater than women but there are some exceptions. Specifically, no significant differences appear in the network of acquaintances among people with higher or medium levels of education, those younger or middle aged, employed, and single. In relation with occupational status a slight variation was found, since in this case there are no significant differences in any of the groups defined by this variable, except for those who work as middle range supervisors.

In summary, our data partially support the claim of Moore (1990) that there are gender differences in the type of social network: the network of the family type is more common among women than among men, although in our data this difference is not statistically significant, and the networks based on friends and acquaintances are most common among men. Furthermore, for these last two types of networks, although some differences in favour of men hold true in the presence of the control variables, in other cases similar to those mentioned when analyzing network accessibility or network mobility, these differences disappear. 


\section{Social participation and gender}

The first salient result for this indicator of social capital is that, according to the data obtained in Spain, participation levels are low (Table 6) in comparison with the results obtained from the World Values Survey, 2001 (Norris and Inglehart, 2006: 86) for post-industrial societies. On average the number of organisations to which both men and women belong in Spain is inferior to one, because more than half of interviewees claimed not to be members of any of the organisations included in the survey list.

Regarding our hypothesis, data show the existence of vertical segmentation in Spain, since there is a significant difference in the mean of membership to voluntary organisations in favour of men.

Moreover, once the various control variables are taken into account, in almost all cases women have a lower average of civic participation than men and most of these differences are significant, with the exceptions of the groups with low education, an older age, intermediate and lower occupational status, which are those with lower levels of participation.

That is, men generally have higher levels of civic participation than women and, unlike the data observed with regard to network accessibility or network mobility, the effect of structural factors do not follow the same direction and have less power in diminishing gender differences.

Table 6. Mean of organisational membership according to gender and control variables

\begin{tabular}{|c|c|c|c|c|c|}
\hline & & Women & Men & Difference & Sig. 1 \\
\hline \multirow[t]{2}{*}{ All } & & 0.75 & 0.94 & -0.19 & $\star * \star$ \\
\hline & High & 1.12 & 1.29 & -0.17 & * \\
\hline \multirow[t]{3}{*}{ Education } & Moderate & 0.61 & 0.87 & -0.26 & $* * *$ \\
\hline & Low & 0.49 & 0.47 & 0.02 & n.s \\
\hline & Under 35 & 0.61 & 0.89 & -0.28 & $* \star *$ \\
\hline \multirow[t]{3}{*}{ Age groups } & $35-64$ & 0.87 & 1.04 & -0.17 & $* *$ \\
\hline & 65 or more & 0.64 & 0.74 & -0.10 & n.s \\
\hline & $\begin{array}{c}\text { Manager/profe } \\
\text { ssional }\end{array}$ & 1.21 & 1.61 & -0.40 & * \\
\hline \multirow{3}{*}{$\begin{array}{l}\text { Occupational } \\
\text { status }\end{array}$} & $\begin{array}{c}\text { Middle range } \\
\text { supervisors }\end{array}$ & 1.25 & 1.32 & -0.07 & n.s \\
\hline & $\begin{array}{l}\text { Skilled } \\
\text { working }\end{array}$ & 0.64 & 0.78 & -0.14 & n.s \\
\hline & $\begin{array}{l}\text { Unskilled } \\
\text { working }\end{array}$ & 0.48 & 0.63 & -0.15 & n.s \\
\hline \multirow[b]{2}{*}{ Work status } & In paid work & 0.96 & 1.10 & -0.14 & * \\
\hline & $\begin{array}{l}\text { Not in paid } \\
\text { work }\end{array}$ & 0.60 & 0.76 & -0.16 & ** \\
\hline \multirow[t]{2}{*}{ Marital status } & $\begin{array}{l}\text { Married or } \\
\text { cohabiting }\end{array}$ & 0.81 & 1.02 & -0.21 & $* * *$ \\
\hline & Single & 0.65 & 0.80 & -0.15 & * \\
\hline \multirow{2}{*}{ Dependants } & Yes & 0.91 & 1.09 & -0.18 & ** \\
\hline & No & 0.67 & 0.87 & -0.20 & $* * *$ \\
\hline
\end{tabular}

Source: Author, based on data from OSIM Survey on social capital in Spain, 2011.

1 Level of statistical significance of ANOVA: n.s. = not significant, ${ }^{*}: p \leq 0.05 ;{ }^{* *}: p \leq 0.01 ;{ }^{* *}: p \leq 0.001$

One possible explanation for differences in the level of participation could be found in the type of organisations included in the list because of the so called horizontal segmentation that is reflected in the gender inequality of the membership of different kinds of organisations.

As shown in Table 7, in most organisations there are significant differences between the percentages of male and female membership. On the one hand, there is a negative balance for women in trade unions, professional associations, associations related to ecology and the environment and, especially, in sports organisations. On the other hand, the balance for women is positive in religious 
organisations and humanitarian or charitable NGOs. There are also two types of organisations, political parties and cultural and educational associations, in which, although the balance is negative for women, the difference is not significant.

Table 7. Membership percentage of voluntary organisations according to gender

\begin{tabular}{|c|c|c|c|c|}
\hline & Women & Men & Difference & Sig. 1 \\
\hline Religious organisations & 10.00 & 8.00 & 2.00 & * \\
\hline Sports organisations & 8.30 & 19.80 & -11.50 & $* * *$ \\
\hline Art. music or educational organisations & 13.10 & 15.10 & -2.00 & n.s. \\
\hline Trade unions & 8.50 & 13.30 & -4.80 & $* * *$ \\
\hline Political parties & 3.90 & 4.10 & -0.20 & n.s. \\
\hline $\begin{array}{l}\text { Associations related to ecology and } \\
\text { environmental associations }\end{array}$ & 4.00 & 6.00 & -2.00 & ** \\
\hline Professional associations & 5.60 & 9.30 & -3.70 & *** \\
\hline $\begin{array}{c}\text { NGOs (Social welfare. health. human rights. } \\
\text { humanitarian) }\end{array}$ & 19.90 & 17.30 & 2.60 & * \\
\hline
\end{tabular}

Source: Author, based on data from OSIM Survey on social capital in Spain, 2011.

1 Level of statistical significance Chi-square: $n . s .=$ not significant, ${ }^{*}: p \leq 0.05 ;{ }^{* *}: p \leq 0.01 ;{ }^{* * *}: p \leq 0.001$

Our results are consistent with those obtained by McPherson and Smith-Lovin (1982), Norris and Inglehart (2006), Lowndes (2006) and Caiazza and Gault (2006), which found that predominantly male organisations are those related with economic matters that offer opportunities for advancement, and also those related with sports. Meanwhile women tend to adhere to organisations focused on the household, on community problems and helping others, as well as religious organisations, generally related to traditional feminine roles.

Nevertheless, we have to clarify some of the above differences. Since certain types of organisations, in which the balance is negative for women, are clearly related to the labour market, employment status has to be taken into account as a control variable. In fact, it has been found that when considering only the people who are in paid employment, although there is still a slight negative balance for women's membership in trade unions and professional organisations, such balance is no longer significant (Table 8).

Regarding membership of associations related to the environment, ecology, animal rights and non-governmental organisations, gender differences diminish in intensity when considering control variables, for example, among younger people where these differences are no longer significant. Gender differences in terms of membership of religious organisations among young people are neither significant, and the balance is even reversed, as the percentage of men belonging to these organisations is slightly higher than the percentage of women. These results seem to indicate that the changes in the last decades in the gender role expectations are being reflected in the new generations.

Table 8. Membership percentage of voluntary organisations according to gender, among selected categories of several control variables

\begin{tabular}{|c|c|c|c|c|}
\hline & Women & Men & Difference & Sig.1 \\
\hline $\begin{array}{l}\text { Trade union membership among those with } \\
\text { paid work }\end{array}$ & 15.2 & 16.9 & -1.7 & n.s. \\
\hline $\begin{array}{l}\text { Professional associations membership among } \\
\text { those with paid work }\end{array}$ & 10.6 & 13.3 & -2.7 & n.s. \\
\hline $\begin{array}{c}\text { Membership of associations related to ecology } \\
\text { and environmental associations among young } \\
\text { people (under 35) }\end{array}$ & 3.1 & 5.6 & -2.5 & n.s. \\
\hline $\begin{array}{l}\text { Religious organisations membership among } \\
\text { young people (under } 35 \text { ) }\end{array}$ & 4.6 & 6.6 & -2.0 & n.s. \\
\hline
\end{tabular}

Source: Author, based on data from OSIM Survey on social capital in Spain, 2011.

1 Level of statistical significance Chi-square: $n . s .=$ not significant, ${ }^{*}: p \leq 0.05 ;{ }^{* *}: p \leq 0.01 ;{ }^{* * *}: p \leq 0.001$

Finally, in relation to sports organisations, it is noteworthy that gender differences in favour of men remain and are significant even when considering all the control 
variables (Table 9) since men have, for all groups, higher membership percentages to these organisations than women. Neither the fact of participating or not in the labour market nor the level of education affects the different membership of men and women of these organisations; variables that in other cases have reduced gender inequality.

Table 9. Membership percentage of sports organisations according to gender and control variables

\begin{tabular}{|c|c|c|c|c|c|}
\hline & & Women & Men & Difference & Sig. 1 \\
\hline \multirow[t]{2}{*}{ All } & & 8.30 & 19.80 & -11.5 & $\star \star \star *$ \\
\hline & High & 4.3 & 12.4 & -8.1 & *** \\
\hline \multirow[t]{3}{*}{ Education } & Moderate & 7.5 & 19.4 & -11.9 & $* * *$ \\
\hline & Low & 12.2 & 23.9 & -11.7 & $* * *$ \\
\hline & Under 35 & 7.1 & 25.7 & -18.6 & *** \\
\hline \multirow[t]{3}{*}{ Age groups } & $35-64$ & 10.4 & 19.6 & -9.2 & $* * *$ \\
\hline & 65 or more & 5.0 & 10.4 & -5.4 & *** \\
\hline & $\begin{array}{c}\text { Manager/profession } \\
\text { al }\end{array}$ & 9.0 & 27.9 & -18.9 & $* * *$ \\
\hline \multirow[t]{3}{*}{$\begin{array}{l}\text { Occupationa } \\
\text { I status }\end{array}$} & $\begin{array}{l}\text { Middle range } \\
\text { supervisors }\end{array}$ & 13.7 & 26.6 & -12.9 & *** \\
\hline & Skilled working & 6.6 & 15.2 & -8.6 & $* * *$ \\
\hline & Unskilled working & 4.4 & 20.3 & -15.9 & *** \\
\hline \multirow{2}{*}{ Work status } & In paid work & 10.3 & 22.7 & -12.4 & *** \\
\hline & Not in paid work & 6.9 & 16.4 & -9.5 & $* * *$ \\
\hline \multirow{2}{*}{$\begin{array}{l}\text { Marital } \\
\text { status }\end{array}$} & $\begin{array}{l}\text { Married or } \\
\text { cohabiting }\end{array}$ & 9.6 & 19.0 & -9.4 & *** \\
\hline & Single & 7.6 & 21.5 & -13.9 & *** \\
\hline \multirow{2}{*}{ Dependants } & Yes & 12.2 & 20.3 & -8.1 & $* * *$ \\
\hline & No & 6.3 & 19.6 & -13.3 & $\star * *$ \\
\hline
\end{tabular}

Source: Author, based on data from OSIM Survey on social capital in Spain, 2011.

1 Level of statistical significance Chi-square: $n . s .=$ not significant, ${ }^{*}: p \leq 0.05 ;{ }^{* *}: p \leq 0.01 ;{ }^{* * *}: p \leq 0.001$

In summary, we have found that there is a horizontal segmentation in terms of civic participation in line with other studies, since the rates of participation of men and women vary according to the type of organisations under consideration. However, it is true that the segmentation is reduced in most cases by introducing control variables, except when considering membership of sport organisations.

\section{Conclusions}

In this analysis of social capital in Spain, we have found clear gender differences in diverse measures of social capital, supporting our hypotheses. As for the extension and use of social capital, there are gender inequalities, in favour of men on the accessibility and possible use or mobilisation of resources embedded in social networks. Regarding the type of social capital, the family network density is slightly more common among women and networks based on friends and acquaintances are more common among men. Civic participation is also higher for men than for women, and the differential types of organisations to which men and women belong show the existence of a gendered horizontal segmentation.

However, the differences in accessibility, mobilisation, type of network and horizontal segmentation are affected by the introduction of structural factors. In this way, inequality between men and women disappears when we consider the groups in more advantageous social positions: that is the highly educated and those with higher occupational status; those in situations that allow contact with greater and more varied groups, which are related to the fact of having paid employment; or the younger age groups that have been educated in less traditional gender roles. In general, gender inequalities remain in all the other groups. It is only with regards to civic participation that control variables do not reduce gender differences in the same direction as in the above cases. One possible explanation for the persistence of this vertical segmentation could be related with the time restriction derived from the fact that women still continue to do most of the housework, a variable not 
included in the dataset analysed, since time is an unavoidable factor to participate in social organisations. The impact of the time distribution of housework by gender in the inequalities in social capital could open new lines of inquiry. Future research may also focus on an in-depth multivariate analysis of the relationships found between social capital and various structural factors, as well as the extension of the analysis to the international comparison to confirm if results in other countries are similar to those found in Spain.

Finally, we might wonder whether our findings of a lower level of social capital among women could also be due to the fact that part of women's social capital is invisible to the standard measurements. Perhaps we need to explore other forms of political participation and civic engagement, as noted by Dieltlind Stolle and Michele Micheletti (2006) when analyzing the behaviour, motivations and consumer decisions for political reasons, and explore other areas of relationships, as proposed by Maxine Molyneux (2008), since women tend to develop their links and networks in fields different to those of men.

\section{Bibliography}

Adler, Paul S. and Seok-Woo Kwon (2002) 'Social Capital: Prospects for a New Concept', Academy of Management Review 27(1): 17-40.

Bourdieu, Pierre (1985) 'The forms of capital', in John G. Richardson (ed.) Handbook of Theory and Research for the Sociology of Education. New York, NY: Greenwood Press, pp. 241-258.

Caiazza, Amy and Barbara Gault (2006) 'Acting from the Heart: Values, Social Capital and Women's Involvement in Interfaith and Environmental Organizations', in Brenda O'Neill and Elisabeth Gidengil (eds) Gender and Social Capital. New York, NY: Routledge, pp. 99-126.

Coleman, James (1988) 'Social Capital in the Creation of Human Capital', American Journal of Sociology 94(Supplement): 95-120.

Dasgupta, Partha and Ismail Serageldin (eds.) (2001) Social capital, a multifaceted approach. Washington, D.C.: The World Bank.

Huanga, Jian, Henriëtte Maassen van den Brinka and Wim Groota (2009) 'A MetaAnalysis of the Effect of Education on Social Capital', Economics of Education Review 28(4): 454-464.

Kroll, Christian (2011) 'Different things make different people happy: examining social capital and subjective well-being by gender and parental status', Social Indicators Research 104(1) 157-177.

Lin, Nan (2000) 'Inequality in Social Capital', Contemporary Sociology 29 (6): 785795.

Lowndes, Vivien (2006) 'It's Not What You've Got, But What You Do With It: Women, Social Capital and Political Participation', in Brenda O'Neill and Elisabeth Gidengil (eds) Gender and Social Capital. New York, NY: Routledge, pp. 213-240.

McPherson, J. Miller and Lynn Smith-Lovin (1982) 'Women and Weak Ties: Differences by Sex in the Size of Voluntary Organizations', American Journal of Sociology 87 (4): 883-904.

Molyneux, Maxine (2008) 'La política de desarrollo y la dimensión de género del capital social', Papeles 101: 64-79.

Moore, Gwen (1990) 'Structural Determinants of Men's and Women's Personal Networks', American Sociological Review 55(5): 726-35. 
Norris, Pippa and Inglehart, Ronald (2006) 'Gendering Social Capital. Bowling in Women's Leagues?', in Brenda O'Neill and Elisabeth Gidengil (eds) Gender and Social Capital. New York, NY: Routledge, pp. 73-98.

Putnam, Robert D. (1995) 'Bowling alone: America's declining social capital', Journal of Democracy 6(1): 65-78.

Putnam, Robert D. (2000) Bowling alone: The collapse and revival of American community. New York, NY: Simon and Schuster.

Stolle, Dietlind and Michele Micheletti (2006) 'The Gender Gap Reversed: Political Consumerism as a Women-Friendly Form of Civic and Political Engagement' in Brenda O'Neill and Elisabeth Gidengil (eds) Gender and Social Capital. New York, NY: Routledge, pp. 45-72.

Timberlake, Sharon (2005) 'Social capital and gender in the workplace', Journal of Management Development 25(1): 34-44. 